fall. During the six years that Brown kept a henhouse, a dozen adult chickens were taken before he could kill the hawks, a total known loss of about twenty-five dollars.

The losses from six species of hawks, and from the Bald Eagle, Crcw and Raven, over a period of fourteen years, can be summed up as follows:

From the Crow's egg stealing $\$ 60.00$ From the Cooper's Hawk ........ 10.00

From the Goshawk

TOTAL

$\$ 95.00$

The conservationist might well compare this figure with losses from animals over which these birds exercise some control. Mice in the granary did about twenty dollars damage a year, squirrels carried off bushels of corn, pocket gophers plagued the hay meadows. Losses from these sources must have added up to three or four times the amount charged to the hawks. To be fair, one should add that had the young chickens and turkeys been exposed, losses would have been greater. Also, a certain loss might have occurred unnoticed.

Of the owrls, the smaller species, the Short-eared, Screech and Sawwhet, caused no trouble. The Snowy Owl was rare in the area, and was also never suspected of molesting the poultry. On the other hand, the Barred Owl, quite abundant, took young poults that had been moved into open shelters from the brooder house prematurely. Once old enough to be moved to their customary ranges, young turks were not attacked. Total number of poults taken by these owls was estimated at fifteen, all young, so that the financial loss was not over thirty dollars.

The real villain of the piece was the Great Horned Owl. The Horned Owl turned at once from his native prey to the turkeys. Attacks were made at night, and the owl killed even grown birds (weighing from twelve to seventeen pounds, compared to the owl's three or four). Brown was unable to estimate the damage suffered by the flocks from the Horned Owl because the loss from continual harassing was much more serious than the loss from actual fatalities, although these were numerous enough. The nervous reaction of the turkeys to the Horned Owl's attacks resulted in lost weight and finish in the dressed birds.

In spite of his own experience, Brown does not name the Horned Owl as 'everybody's enemy. His poultry were raised in a remote area where the owl was native, and many farms are much less exposed. The aim of his whole article is to persuade poultry growers not to act against the predatory birds without cause. He does this by calculating in as fair a manner as possible the exact capacity of these birds for harm.

\title{
Alberta Controversy Re: Protection of Birds of Prey
}

In Saskatchewan, the following birds of prey are not protected by provincial law: Snowy Owl, Great Horned Ow l, Goshawk, Pigeon Hawk, Duck Hawk, Cooper's Hawk, Sharp-shinned Hawk. In Alberta, on the other hand, all hawks and owls are protected. However, two resolutions have come recently from the Calgary Fish and Game Association asking for a modification of this blanket protection. These resolutions read as follows:

1. "Whereas the Horned Owl is a voracious, wide-ranging hunter and whereas they are proved to be detrimental to our game bird population and whereas they are now protected and whereas they have no natural enemies and no natural control except food conditions and whereas it is extremely. unlikely that they will ever become extinct due to hunting, therefore be it resolved that Horned Owls be placed on the predator list."

2. "Whereas the M a rsh Hawk, Sharp-shinned Hawk, Snowy Owl, Goshawk, Cooper's Hawk, Duck Hawk and Pigeon Hawk are harmful to our game bird population and whereas they are now on the protected list, therefore be it resolved that these hawks be placed on the predator list." 
There has just come to the Editor's desk a brief prepared by the Predator Committee of the Edmonton Bird Club as a contribution to a joint discussion with the Calgary Fish and Game Association on the subject of predatory birds. The brief begins with a statement of the basic reason why blanket protection has been afforded the birds of prey in Alberta: That neither one hunter in a thousand, nor any of the boys with .22 rifles, is able to distinguish in the field between the numerous beneficial species and the few controversial ones, resulting in indiscriminate slaughter.

The most significant part of the brief is its report on an intensive research programme carried on by the Edmonton Bird Club involving stomach and pellet analyses and nest observations. The Alberta statistics studied show:

HORNED OWL: 73 records - 122 beneficial or non-game food items, 14 game items (5 Coots, 3 Mallards, 1 Hun, 1 Ruffed .Grouse, 1 Sharp-tailed Grouse, 1 Pheasant). Conclusion: "It is evident that game predation by the Great Horned Owl varies greatly with local conditions throughout the country and with the seasons. Alberta evidence to date shows that the Snowshoe Hare is the chief food item of this owl, but when hares are scarce and if game predation should be proved excessive, it may be desirable to introduce control measures, exercised by competent men during times of demonstrated predation only."

MARSH HAWK. 61 records - 66 beneficial or non-game food items, 10 game items ( 3 ducks, all Botulism-infected; 3 ducks, being eaten as carrion after having been wounded or killed by shot; 1 Pintail duckling; 1 Hungarian Partridge; 1 Wilson's Snipe; 1 Snow Goose, being eaten as carrion having been killed by shot).

Conclusion: "It is obvious that predation of healthy game birds is extremely light and that at the moment we have insufficient evidence to warrant control."

SHARP-SHINNED HAWK. 2 records only - no game birds.

Conclusion: "Present evidence would indicate that this species has no effect on game bird populations in Alberta."

SNOWY OWL. 14 records - 16 beneficial or non-game food items, 4 game items ( 1 wounded duck, 2 Mallards, 1 Hungarian), and in addition numerous wounded Mallards, dead or dying at water holes. Conclusion: "As the Snowy Owl is an irregular visitor during the winter months, and tends to restrict its food habits to beneficial or non-game food items, mainly mice, it appears that there is insufficient evidence to warrant controls on this species."

GOSHAWK. 8 records. 5 beneficial or non-game items, 4 game items (1 Hun, 1 Ruffed Grouse, 1 Spruce Grouse, 1 Pheasant investigated and proved to have been killed by gunshot).

Conclusion: "Insofar as game interests are concerned, the Goshawk is undoubtedly the most suspect species. If game predation is proved to be particularly heavy in specific areas, control measures should be exercised but only by competent field men and within the limits of these predation areas."

COOPER'S HAWK. No Alberta statistics, as there are so few authentic records of its presence in the province.

DUCK HAWK. 9 records - 12 nongame food items, 3 game items, ( 1 Coot, 1 Mallard, 1 Hun).

Conclusion: "The fact that this bird is nowhere common in Alberta is sufficient evidence that it can have little economic effect on game bird populations."

PIGEON HAWK. 4 records - no game items.

Conclusion: "The limited numbers of this small falcon in Alberta make it a negligible factor in game predation."

The conclusion drawn from this study is stated in the brief as follows: "It appears that there is little evidence in Alberta to warrant controls on any of the above-mentioned species. However, if control measures are proved to be justifiable in the case of the Goshawk and the Horned Owl, it is an absolute necessity that such measures be enforced by competent field men able to distinguish the various species, in order to prevent indiscriminate slaughter."” 